\title{
RESILIENCE, RELIGIOUS ORIENTATION, AND EMOTION REGULATION AMONG FIRST-YEAR THEOLOGICAL STUDENTS
}

\author{
Elisabeth Sitepu ${ }^{1} 凹$, May Rauli Simamora ${ }^{2}$, Johanes Waldes Hasugian ${ }^{3}$ \\ Communication Studies, Universitas Darma Agung, Indonesia. \\ 2 Pastoral Counseling, Institut Agama Kristen Negeri Tarutung, Indonesia. \\ ${ }^{3}$ Christian Religious Education, Sekolah Tinggi Teologi Sumatera Utara, Indonesia
}

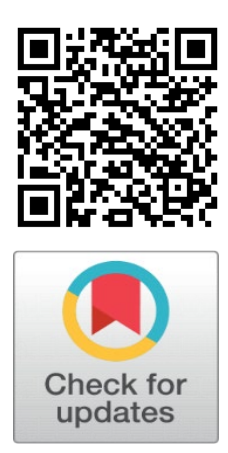

Received 1 September2021

Accepted 15 September 2021

Published 30 September 2021

\section{CorrespondingAuthor}

Elisabeth Sitepu,

elisabeth.sitepu20@gmail.com

DOI

10.29121/granthaalayah.v9.i9.2021. 4147

Funding: This research received no specific grant from any funding agency in the public, commercial, or not-for-profit sectors.

Copyright: (C) 2021 The Author(s). This is an open access article distributed under the terms of the Creative Commons Attribution License, which permits unrestricted use, distribution, and reproduction in any medium, provided the original author and source are credited.

\section{ABSTRACT}

The purpose of this study was to determine the relationship between religious orientation, emotion regulation, and resilience of first-year theological students. The total sample used in this study was 59 first-year theological students at a theological college in Indonesia. The results show a statistically significant positive relationship between religious orientation, emotion regulation, and resilience. The results also show that the effective contribution of emotion regulation is higher than the religious orientation towards resilience. These results indicate the importance of emotional regulation training and religious orientation education to develop resilience in the lives of first-year theological students.

Keywords: First-Year Theological Students; Resilience; Religious Orientation; Emotion Regulation

\section{INTRODUCTION}

The transition from High School to College challenges students to adjust or adapt to new experiences on campus. Poor adaptation and transition on campus can lead to poor student experiences and eventual dropout Pickard et al. (2017). The research showed that students who dropped out in the first academic year had a low willingness and effort to learn and low persistence when faced with difficulties, often doubted their abilities, and felt less in control of their actions Ayala and Manzano (2018). This study is associated with the student's ability to survive as an essential factor in supporting the academic achievement of firstyear students and preventing dropouts Ayala and Manzano (2018). First-year students can be identified as early adults going through a transitional period from adolescence to adulthood. Resilience is one of the personality traits that can help early adulthood overcome life's difficulties because early adulthood is a very flexible period full of transitions and uncertainties Nartova-Bochaver et al. (2021). Likewise, students on theological college must also experience transitions and adaptations in their first year in attending lectures, where in order to be able to excel and not drop out of school, they need resilience in themselves.

Psychologists define resilience as the process of adapting well in the face of adversity, trauma, tragedy, threats, or significant sources of stress, such as family and relationship problems, serious health problems, or stressors at work and finances APA (2012). Resilience can also be considered a measure of success in 
overcoming stress Connor and Davidson (2003). By developing resilience, individuals will face life difficulties or stress that often cannot be prevented or rejected but must be overcome. As prospective pastors, missionaries, and educators, theological students must be able to endure various difficulties in their own lives so that later they can help other people or the congregation to survive or rise again from life's difficulties.

Resilience is studied by researchers from various disciplines, including psychology, psychiatry, sociology, biological disciplines (genetics, epigenetics, endocrinology, and neuroscience), including, more recently, theology Herrman et al. (2011), Panganiban (2020). Resilience is also studied in the Bible. In the Chapter on Ruth, the resilience of the character Ruth is developed by caring for others, identifying with specific religious communities, and taking the initiative while maintaining integrity Panganiban (2020). The next character is Joseph, who is resistant to the temptations of Potiphar's wife and even the slander addressed to him because of his firm stance and fear of God. We can see the same thing in Daniel and his three friends Shadrach, Meshach, and Abednego, who are under pressure to worship other kings and gods. In any of these ways, Daniel could get through his difficult time in lion's cave, and his three friends escaped the threat of the blazing fireplace. Another character in the Bible who has resilience is Jesus, who suffered humiliation and was tortured to death on the cross. Paul and several other disciples of Jesus experienced suffering for preaching the gospel of Christ.

Theological students are expected to internalize Christian values in themselves in living their lives both academically and non-academically. Theological students also have to apply and live in their religious beliefs, faith, and religious values. The way to apply this is known as religious orientation, which consists of an intrinsic and extrinsic religious orientation framework Allport (1966). Thus, their religious orientation is related to the resilience they have. Religiosity has been studied concerning resilience. Research shows a significant positive relationship between religious orientation and resilience in academic students Javanmard (2013), Seidmahmoodi (2011). Dehghani and Andishmand (2017) also support their research that religious orientation is related to resilience. Recent research shows the importance of religiosity because there is a significant positive relationship between religiosity and resilience Al Eid et al. (2020).

Emotion is an essential aspect of resilience. The research concluded that Ruth's resilience is shown through her words and actions in every event of her life Panganiban (2020). She also has the strength of mind, emotion, and spirit, although in vulnerability. Emotions need to be managed in order to survive in life. Previous studies have proven the relationship between emotion regulation and resilience. Emotion regulation, such as increasing positive emotions and reducing negative emotions, is essential to learn and practice as an effective strategy for resilience Kay (2016). The ability to regulate emotions has been shown to predict resilience in adolescents Mestre et al. (2017).

Based on the explanation above, two research hypotheses are proposed. First, there is a positive relationship between religious orientation and resilience. A high level of resilience will follow the high level of religious orientation. Second, there is a positive relationship between emotion regulation and resilience. That is, a high level of emotional regulation will be followed by a high level of resilience. 


\section{MATERIALS AND METHODS}

\section{Participants}

The population in this study were 67 first-year theological students who were registered and active in Institut Agama Kristen Negeri Tarutung, with a total of 59 respondents who were willing to take part in the study, and all of the respondents provided their written informed consent to participate in this study and to publish the results anonymously. The sample consisted of $37.3 \%$ males and $62.7 \%$ females (Mean age $=19.80$, SD age $=0.97$ ). All participants were students of a theological college in North Sumatra, Indonesia; data were collected as a part of their homework on "General Psychology" conducted by the authors during May 2021 using Google form.

\section{Materials}

First of all, the original CD-RISC-10 Nartova-Bochaver et al. (2021), revised I/ER-14 items Darvyri et al. (2014), and modified ERQ-10 items Gross and John (2003) were translated into Bahasa separately by three groups of theological students; they discussed edited items and made items relevant and easy to read. Secondly, a bilingual expert examined the draft questionnaire regarding possible word differences, clarity, and accuracy. After this check, the item list is again slightly edited. Third, the final version was given to 49 students to check if the words were easy to understand. After all this check, no more editing was required.

\section{Data Analysis}

Pearson correlation coefficient was calculated to determine the relationship between religious orientation and emotion regulation with first-year student resilience. In addition, the contribution of religious orientation and emotion regulation was also calculated using the Enter Regression method. All the analyzes were conducted using the SPSS program, version 24.

\section{RESULTS AND DISCUSSIONS}

Cronbach's $\alpha$ reliabilities for the scales are shown along the diagonal in Table 1. The Cronbach alpha coefficient for resilience was 0.83 , the Cronbach alpha coefficient for religious orientation was 0.69 , and the alpha coefficient for emotion regulation was 0.81 . This value indicates that all scales can and are feasible to be used as research instruments. Table 1 shows the Pearson correlation value between religious orientation and resilience is $r=0.47$, positive and very significant $(p<$ 0.001). That is, there is a strong and very significant positive relationship between religious orientation and resilience. Thus, the first hypothesis in this study can be accepted. These results indicate that the higher score of resilience will follow the score of religious orientation. Furthermore, the Pearson correlation value between emotion regulation and resilience in Table 1 shows $r=0.54$, positive and very significant $(\mathrm{p}<0.001)$. That is, there is a strong and very significant positive relationship between emotion regulation and resilience. Thus, the second hypothesis in this study can also be accepted. These results indicate that the higher score of resilience will follow the score of emotion regulation. The results of the research above indicate that the two hypotheses proposed can be accepted. 


\begin{tabular}{|c|c|c|c|c|c|}
\hline & Mean & $\begin{array}{l}\text { Standard } \\
\text { Deviation }\end{array}$ & Resilience & $\begin{array}{c}\text { Religious } \\
\text { Orientation }\end{array}$ & $\begin{array}{c}\text { Emotion } \\
\text { Regulation }\end{array}$ \\
\hline Resilience (10 items) & 36.03 & 6.34 & $(0.83)$ & & \\
\hline $\begin{array}{l}\text { Religious Orientation } \\
\text { (14 items) }\end{array}$ & 52.20 & 6.10 & $0.47^{* * *}$ & $(0.69)$ & \\
\hline $\begin{array}{c}\text { Emotion Regulation (10 } \\
\text { items) }\end{array}$ & 37.54 & 5.83 & $0.54^{* * *}$ & $0.35^{* *}$ & $(0.81)$ \\
\hline
\end{tabular}

$* * * \mathrm{p}<.001 ; * * \mathrm{p}<.01 ;{ }^{*} \mathrm{p}<.05$.

Furthermore, Table 2 shows the Beta value to determine the contribution of each independent variable to the dependent variable. The Beta value between religious orientation and resilience is 0.326 , and between emotion regulation and resilience is 0.426 . So, the contribution of religious orientation to predict resilience is $0.474 \times 0.326=0.154$. The contribution of emotion regulation to predict resilience is $0.54 \times 0.426=0.230$. Religious orientation accounted for $15.4 \%$, and emotion regulation accounted for $23 \%$. The results shown in Table 2 show that religious orientation and regulation accounted for 0.384 or $38.4 \%$. The results also show that the most influential factor in predicting resilience was emotion regulation than religious orientation.

Table 2 Results of regression analysis of resilience on religious orientation and emotion regulation

\begin{tabular}{|cccccc}
\hline & Beta & Contribution & R Square & F & Sig. \\
\hline Religious Orientation & 0.326 & 0.154 & & 0.005 \\
\hline Emotion Regulation & 0.426 & 0.230 & & 0.000 \\
\hline Reggression Analysis & & & 0.384 & 17.447 & 0.000 \\
\hline
\end{tabular}

Dependent variable: Resilience

Many researchers have investigated several factors that affect resilience. Personal factors (personality traits, internal locus of control, mastery, self-efficacy, self-esteem, optimism, intellectual functioning, cognitive flexibility, demographic factors, social relationships, emotional regulation, religious orientation, and others), biological (adrenal steroid hormones), cortisol, and dehydroepiandrosterone, and others), Environmental-Systemic (microenvironmental and macro systemic level), the interaction of the three personal, biological and environmental-systemic are factors that can affect resilience Herrman et al. (2011). Thus, the results of this study support previous studies regarding the relationship between religious orientation and emotion regulation with resilience. This study is in line with research conducted that shows the importance of religious orientation in resilience Al Eid et al. (2020), Dehghani and Andishmand (2017), Javanmard (2013), Seidmahmoodi et al. (2011). In addition, emotion regulation is essential to learn and survive amid life's difficulties Kay (2016).

Intimate relationship or attachment is an essential concept for resilience Herrman et al. (2011). An intimate relationship with God is owned by religious individuals who are very attached to religious beliefs and values and are even 
willing to sacrifice themselves for the future of religion and God Cirhinlioğlu \& Özdikmenli-Demir (2012). These individuals are people with an intrinsic religious orientation. Meanwhile, extrinsically, religious individuals are influenced by social, cultural, and economic conditions prevailing in their country Cirhinlioğlu \& Özdikmenli-Demir (2012). Religion is seen as an essential factor in increasing the resilience of Muslims Al Eid et al. (2020). Likewise, according to the results of this study, religion is also essential for their resilience in Christians' life. In this study, the contribution of religious orientation to the increase in resilience in first-year theological students was $15.4 \%$. Theological students will try hard to live according to their religious beliefs because religion offers comfort in times of trouble and sadness. Just like Ruth, a character in the Bible who has hope in God, keeps her going, increasing determination and resilience Panganiban (2020).

Furthermore, emotion regulation also plays an essential role in resilience. By developing the ability to regulate emotions, individuals will perceive themselves to adapt and face the difficulties of adolescent life Mestre et al. (2017). Likewise, firstyear theological students who transition from adolescence to adulthood must experience difficulties in their lives. Theological students who can regulate their emotions well will change their minds to feel more positive emotions. They will also be able to store and control their emotions and change how they see their life situations. Like Ruth's character in the Bible, her resilience ability is demonstrated through the use of her emotional power, which is rooted in a strong knowledge of her identity and commitment Panganiban (2020). When students realize their identity, they will learn to manage their emotions to face life's difficulties while studying. In this study, the contribution of emotion regulation in first-year theological students was an influential factor to predict resilience than religious orientation, which was $23 \%$.

\section{CONCLUSIONS AND RECOMMENDATIONS}

Based on the data analysis, it was found that there was a significant positive relationship between religious orientation and emotion regulation and the resilience of first-year theology students. The results of this study also support previous research on this issue. Therefore, further studies should focus on the religiosity orientation of a sample of final theology students who may experience more difficulties in achieving graduation, how the resilience of final theology students' needs to be investigated further. Programs in the form of emotional regulation training and education on religious orientation for first-year theology students seem to be needed to develop resilience. This training may be helpful, especially for first-year students who need to make many adjustments or transition from adolescence to adulthood.

The main problem that limits the scope of this research is the structure of the sample group. It is composed of only first-year theological students at one theological college in Indonesia. This problem seems to reduce the possibility of generalizing the results to other first-year theology student populations. In addition, this study is done in a quantitative approach, and future research is expected to use a qualitative approach to find various psychological and theological factors related to resilience in detail. 


\section{REFERENCES}

Al Eid, N. A., Alqahtani, M. M. J., Marwa, K., Arnout, B. A., Alswailem, H. S., \& Al Toaimi, A. A. (2020). Religiosity, Psychological Resilience, and Mental Health Among Breast Cancer Patients in Kingdom of Saudi Arabia. Breast Cancer: Basic and Clinical Research, 14, 1-13. Retrieved from https://doi.org/10.1177/1178223420903054

Allport, G. W. (1966). The Religious Context of Prejudice. Journal for the Scientific Study of Religion, 5(3), 447-457. Retrieved from https://doi.org/10.2307/1384172

APA. (2012). Building your resilience. Retrieved from https://www.apa.org/topics/resilience

Ayala, J. C., \& Manzano, G. (2018). Academic performance of first-year university students: the influence of resilience and engagement. Higher Education Research and Development, 37(7), 1321-1335. Retrieved from https://doi.org/10.1080/07294360.2018.1502258

Cirhinlioğlu, F. G., \& Özdikmenli-Demir, G. (2012). Religious orientation and its relation to locus of control and depression. Archive for the Psychology of Religion, 34(3), 341-362. Retrieved from https://doi.org/10.1163/15736121-12341245

Connor, K. M., \& Davidson, J. R. T. (2003). Development of a new Resilience scale: The Connor-Davidson Resilience scale (CD-RISC). Depression and Anxiety, 18(2), 76-82. Retrieved from https://doi.org/10.1002/da.10113

Darvyri, P., Galanakis, M., Avgoustidis, A. G., Pateraki, N., Vasdekis, S., \& Darviri, C. (2014). The Revised Intrinsic/Extrinsic Religious Orientation Scale in a Sample of Attica's Inhabitants. Psychology, 05(13), 1557-1567. Retrieved from https://doi.org/10.4236/psych.2014.513166

Dehghani, F., \& Andishmand, V. (2017). The Relationship of Religious Orientation and Spiritual Health to Resilience among High School Sophomores in Kerman. Journal Of Research on Religion \& Health, 3(4), 66-67. Retrieved from https://journals.sbmu.ac.ir/en-jrrh/article/view/18911

Gross, J. J., \& John, O. P. (2003). Individual Differences in Two Emotion Regulation Processes: Implications for Affect, Relationships, and Well-Being. Journal of Personality and Social Psychology, 85(2), 348-362. Retrieved from https://doi.org/10.1037/0022-3514.85.2.348

Herrman, H., Stewart, D. E., Diaz-Granados, N., Berger, E. L., Jackson, B., \& Yuen, T. (2011). What is resilience? Canadian Journal of Psychiatry, 56(5), 258-265. Retrieved from https://doi.org/10.1177/070674371105600504

Javanmard, G. H. (2013). Religious Beliefs and Resilience in Academic Students. Procedia - Social and Behavioral Sciences, 84, 744-748. Retrieved from https://doi.org/10.1016/j.sbspro.2013.06.638

Kay, S. A. (2016). Emotion regulation and resilience: Overlooked connections. Industrial and Organizational Psychology, 9(2), 411-415. Retrieved from https://doi.org/10.1017/iop.2016.31

Mestre, J. M., Núñez-Lozano, J. M., Gómez-Molinero, R., Zayas, A., \& Guil, R. (2017). Emotion regulation ability and resilience in a sample of adolescents from a suburban area. Frontiers in Psychology, 8, 1-13. Retrieved from https://doi.org/10.3389/fpsyg.2017.01980

Nartova-Bochaver, S., Korneev, A., \& Bochaver, K. (2021). Validation of the 10-Item Connor-Davidson Resilience Scale: The Case of Russian Youth. Frontiers in 


$\begin{array}{lcccc}\text { Psychiatry, } & \text { 12(February), } & \text { 1-7. } & \text { Retrieved } & \text { from } \\ \text { https://doi.org/10.3389/fpsyt.2021.611026 } & & \end{array}$

Panganiban, A. B. (2020). Theology of Resilience Amidst Vulnerability in the Book of Ruth1. Feminist Theology, 28(2), 182-197. Retrieved from https://doi.org/10.1177/0966735019886077

Pickard, L., McKenna, J., Brunton, J. A., \& Utley, A. (2017). Personal development, resilience theory and transition to university for 1st year students. 293-302. Retrieved from https://doi.org/10.4995/HEAD17.2017.5172

Seidmahmoodi, J., Rahimi, C., \& Mohamadi, N. (2011). Resiliency and religious orientation: Factors contributing to posttraumatic growth in Iranian subjects. Iranian Journal of Psychiatry, 6(4), 145-150. Retrieved from https://www.ncbi.nlm.nih.gov/pmc/articles/PMC3395957/ 